\title{
Research on the Strategy of Students' Ability to Innovate in Science and Technology
}

\author{
Ge Suhui, Xu Hui, and Wan Quan
}

\begin{abstract}
Clear the connotation of scientific and technological innovation spirit and ability, and the constituent elements of innovative quality, this paper expounds the advantageous professional the necessity of students' innovation of science and technology quality cultivation, and through the investigation and research, is put forward based on characteristic specialized laboratory, from teacher quality lead, classroom teaching, experiment community, professional competition of science and technology, scientific research innovation projects, innovative start-ups, an application for a patent for the students, improve the students innovative spirit and ability, characteristics and put forward the private undergraduate engineering college and university students of science and technology innovation spirit and ability training strategy.
\end{abstract}

Index Terms-Specialty, innovation, strategy.

\section{INTRODUCTION}

Colleges and universities, the cultivation of innovative talents of science and technology, as a basic value orientation of college innovation education, is from the traditional education mode is given priority to with passing on knowledge to knowledge, ability and quality training of innovative education model changes, the cultivation of the innovative spirit and the quality colleges and universities of the existing new challenges and higher requirements are put forward. College students' innovation spirit and ability of science and technology throughout the whole process of higher education, at present our country colleges and universities have many kinds of ways to the cultivation of the college students' innovation ability, but at the same time it still has a lot of restricting factors to cultivate college students' innovative spirit, mainly includes: the lack of innovation system and the cultural atmosphere, the disadvantages of traditional education system in colleges and universities, teaching concept, old teaching methods, and academic evaluation mechanism is not scientific, the characteristics of this topic will be advantage at the provincial level, aiming at the above problems students as the research object, looking for a new countermeasure of innovative talents cultivation, to explore a new way of

Manuscript received April 3, 2018; revised May 28, 2018. This work was supported in part by the Shandong University Science and Technology Project, Research Project of QingDao Institute of Technology.

The authors are with the QingDao Institute of Technology, China (e-mail: suhuige@126.com,qdgxyxuhui@126.com,wanlibaidu@foxmail.com). science and technology innovative talents cultivation.

\section{Plan And ImPlementation Plan}

The students of private colleges and universities have weak awareness of science and technology innovation, and the main factors of the school are: the cultural atmosphere of cultivating students' innovative quality is not strong; The restriction of traditional education concept; Teachers' innovation quality is not high; Lack of professional guidance in community construction; The practice teaching link is weak. The main factors of students themselves are: unreasonable structure of knowledge; Poor practical ability; Lack of social responsibility; Lack of spirit of exploration; Weak willpower [1]. In order to improve the cultivation of students' innovative quality, the following problems are mainly solved.

1) Improve the scientific research innovation system and cultural atmosphere of the school, and create a scientific and technological innovation environment.

2) To change the negative phenomenon of teachers' participation in scientific research, to build a team of innovative scientific research teachers, and to improve the consciousness and ability of teachers' scientific research and innovation.

3) To change the non-professional phenomenon of students' associations, closely combine the professional direction, and establish a strong scientific and technological society.

4) Change the old and single evaluation mechanism of academic performance and set up innovative credit identification methods.

\section{IMPLEMENTATION PLAN}

\section{A. Measures}

Competitive feature construction run by the local undergraduate colleges and universities at the provincial level professional talent training quality of science and technology innovation model [2]. Based on the quality of the model to the characteristics of professional scientific and technological innovation spirit and ability of talents cultivation model parsing, colleges and universities run by the local characteristics of professional scientific and technological innovation ability of science and technology talent training mode optimization of a new argument, and proposes to increase advantageous professional students of science and technology innovation spirit and ability training strategy [3].The quality model of scientific and technological innovative talents is shown in Fig. 1. 


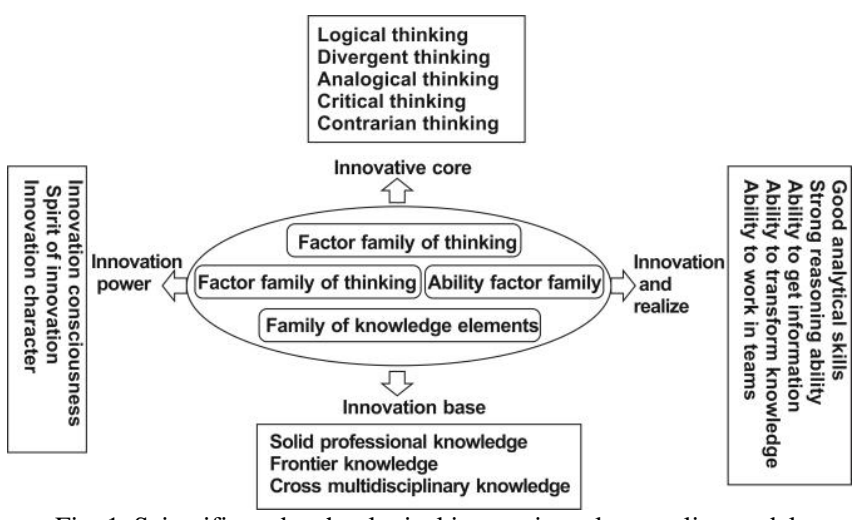

Fig. 1. Scientific and technological innovative talent quality model.

\section{B. Reform Plan Design}

Carry out scientific research innovation, the project of teacher research academic forum on a regular basis, the capability of technological innovation of teachers in the experimental class teaching, the introduction of innovative experimental project in students' daily learning subtly infusion of innovative ideas and strengthen training pertinence and effectiveness of education [4]. Combining with each professional competition of science and technology, to study result is excellent, innovative thinking, active students the opportunity to participate in the innovation of science and technology competition [5].

Establishment of science and technology innovative professional associations, the implementation of college students' scientific research innovation training plan [6]. Establish college students' science and technology thesis writing team, with regular club activities, inspection ability of the students' innovative quality and space.

Equipped with scientific research practice ability strong teachers graded teaching, according to the grade, students, training level etc, to take the differentiation strategy, innovation of science and technology innovation project development reserve talents, cultivating students' innovative consciousness, inspire students' innovative spirit, to improve students' innovation ability [7], [8]. Thus improve the provincial advantageous to cultivate the students' professional quality, set up good brand image feature specialty [9].

The establishment of the association for the creation of scientific and technological inventions has brought together students with the same interests and interests to attract more students to participate in scientific and technological innovation activities.

Aiming at students seeking new and different psychology, establishing discipline competition mechanism and innovation training system, guiding students to participate in various professional science and technology competitions.

Set up an innovation scholarship or innovation fund to create a education environment for the innovative quality training of students with characteristic majors [10].

Strengthen the construction of education platform, actively create conditions, support and encourage students to participate in various disciplines competitions [11]. Innovation projects and scientific and technological activities through innovative platforms.

Create an advanced experimental environment for scientific and technological innovation, strengthen the open policy and management of laboratories, and provide hardware guarantee for students to cultivate innovative spirit

\section{Strategies And Methods}

\section{A. Innovation Points}

Establishing "autonomy is the key, the personality is the base point, the interest is the motive force, the project is driven, the competition is the carrier" the science and technology innovation talent cultivation strategy.

Optimization and gradually formation, interest group student association-innovation training project-discipline competition - innovation BBS - patent application for science and technology innovative talent training mode [12].

\section{B. Desired Effect}

To form a virtuous circle of "internal and external integration, multiple forms of complementary and mutually supportive promotion", and play the role of talent training through innovation training base.

The construction of a kind of "creativity - innovation entrepreneurship", a talent training system with scientific and technological characteristics.

We will optimize the discipline competition system, establish an innovation credit system, combine the disciplines competition with innovation activities, and improve the innovative activity plans of multi-level, multi-type students' independent management and independent innovation.

\section{With the Teacher As the Core, Students Are the SUPPORTING STRUCTURE}

There are many factors to cultivate college students' innovation ability, among which the construction of tutor team is very important. The tutor is the guide of the student, without the guidance of the teacher, the student's innovation activity will linger [13]. Only if the teacher has strong innovation consciousness, innovative thinking method and innovative experience, it is possible to cultivate students with innovative spirit and innovative ability.

The tutorial system of undergraduate students is based on the teacher as the core, and the students are the supporting structure. Structures including lining and perisphere, inner layer is mainly responsible for lower grade students, instructors perisphere main division is responsible for the guidance of the seniors, perisphere senior students should play a leading and mentoring role in the lower grades [14]. Teacher as the core of the tutorial system, special requirements for teachers for every student to make personalized training program, students should be based on different grade, the different professional knowledge level, structure, ability and strength for development direction, teachers with students in different stages of the study and formulate development goals, and target steadily implemented as planned [15]. The tutor should closely combine the actual situation of the students, guide the students to take elective courses, actively participate in 
various practical teaching practices, and strive to cultivate students' autonomous ability and practical ability; Actively guide students to participate in various science and technology competition activities to enhance students' innovation ability. Allow students to fully express themselves and cultivate the students' thinking tendency and critical. The closed-loop feedback innovative talent cultivation control model is shown in Fig. 2.

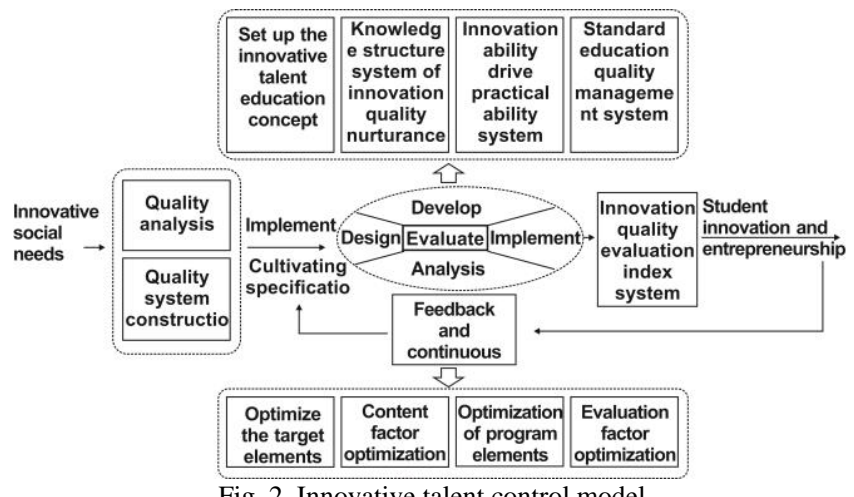

\section{THE CASE STUDY}

This topic with the help of the advantage of shandong province characteristic advantage of the professional computer science and technology, give full play to the laboratory hardware advantage, combined with college students of science and technology innovation projects at the same time, college students' innovative entrepreneurial training plan, professional discipline competition, characteristics of opening laboratory system, student club activities, an application for a patent for the students, and students play feature " $113 \mathrm{~N}$ project" the guidance function of tutor system, tool this professional competency model can be used to the current situation of the development of students' innovative quality and capability analysis evaluation, inductive characteristics professional scientific, technological innovation spirit and ability of talent training quality characteristics, build a matrix of structure is reasonable for the specialty elective course knowledge system, thus improve the body of the excitation characteristics of professional students' innovative quality consciousness, improve the students' innovative quality enhance self expectation.

Actively guide students innovation consciousness to temper character, thus put forward the characteristics of professional students countermeasures for the cultivation of the innovative spirit and ability of science and technology, realizing professional science and technology innovative talents training target, summarizes the creative talents of science and technology developing mode, enrich the theoretical system of the innovative talents of science and technology, improve the level of the cultivation of innovative talents of science and technology, as well as other college quality and ability of the scientific and technological innovation, talent cultivation provide a reference basis.

\section{CONCLUSION}

This topic in theory and practice, points out the advantages of undergraduate course colleges and universities characteristic problems of professional science and technology innovative talents cultivation, and analyzed the cause of the problem, preliminarily summarizes the growth pattern of innovative talents of science and technology; actively explore innovative talents of science and technology of the effective measures and solutions. Put forward and solve these problems, advantageous professional science and technology innovative talents in colleges and universities not only enrich and perfect the theory of a greater role in promoting, at the same time to promote the growth of creative talents of science and technology development, improve the level of science and technology innovative talents in colleges and universities cultivate, promote collaborative innovation and speed up the pace to build an innovation-oriented country college has important practical significance.

\section{ACKNOWLEDGMENT}

I want to take this chance to thanks to Wan Quan and Xu Lingling. In the process of composing this paper, they give me many academic and constructive advices, and help me to correct my paper.

At the same time, I would like to appreciate my research team for the approved fund project, Shandong university science and technology project (J16LN54) and Qingdao University of Technology project (2016JY007/2017KY008).

My team offer me the confidence and give me useful literature knowledge and information in this paper. I thank you all.

\section{REFERENCES}

[1] B. H. Kang, "The development of education and technological innovation ability of college students," Journal of Education College Suzhou, 2018, vol. 2, pp. 30-43.

[2] F. Wang and L. Zhou, "Spatial and temporal evolution and formation mechanism of science and technology innovation capability in China's provincial higher schools," Resource Development and Market, Aug. 8, 2018, pp. 48-52.

[3] A. H. Liu and L. P. Zhang, "A study on the fuzzy comprehensive evaluation of college students' scientific and technological innovation ability," Journal of Shandong Youth Political College, 2016, vol. 4, pp. 29-31.

[4] W. Yang, "Research on the training of college students' scientific and technological innovation ability by relying on science and technology competition and innovative experiment plan," Research on Ideological and Political Education, 2015, vol. 7, pp. 55-62.

[5] Q. Bai, "Research on the cultivation mechanism of college students' scientific and technological innovation ability — The experience and enlightenment of Harvard University," Journal of Chongqing University (Social Science Edition), 2014, vol. 12, pp. 89-92.

[6] G. M. Ji, "Structural construction and cultivation of adolescent science and technology innovation ability," Journal of Shandong Normal University, 2015, vol. 6, pp. 103-107.

[7] C. L. Li and L. L. Liu, "Evaluation of science and technology innovation capability of undergraduate universities in Hebei province - Based on the analysis of the science and technology statistics of universities in 2012-2016," Scientific and Technological Management Research, 2018, vol. 2, pp. 72-75.

[8] M. L. Wu, "Academic competition and cultivation of innovation and entrepreneurial ability of university students — Taking the automobile college of guangxi university of science and technology as an example," Journal of Zhangjiakou Vocational and Technical College, 2017, vol. 9, pp. 88-90.

[9] Y. J. Hao, "A brief discussion on the cultivation of innovative entrepreneurial ability of college students in application-oriented universities - Taking Hebei science and technology normal college as an example," Education Modernization, 2017, vol. 10, pp. 44-46. 
[10] S. Yan and S. Y. Zhou, "The practice and exploration of improving the technological innovation ability of university students - Taking suzhou university of science and technology as an example," Yanbian Education College Journal, 2017, vol. 12, pp. 39-41.

[11] F. Wang and Y. P. Bai, "The spatial and temporal pattern of China's university science and technology innovation ability and its influencing factors," Economic Geography, 2017, vol. 12, pp. 75-78.

[12] Q. Yang Qian, "On how to cultivate and improve college students' technological innovation ability," Bohai Economic Outlook, 2016, vol. 11, pp. 67-71.

[13] L. Men, "Discussion on science and technology innovation competition to improve college students' practical ability," Education Modernization, 2017, vol. 12, pp. 84-89.

[14] S. Q. Chen and S. L. Wang, "The exploration and practice of the university's science and technology innovation ability training for college students, wisdom," 2017, vol. 8, pp. 57-60.

[15] X. Zhang and Z. Li, "Optimizing curriculum setting and improving innovation ability - Taking the postgraduate training program of jiangsu university of science and technology as an example," Higher Education Journal, 2015, vol. 2, pp. 93-95.

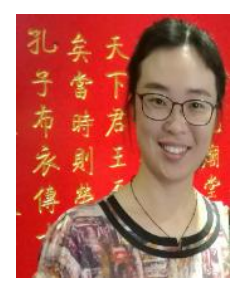

Ge Suhui is lecturer, master, graduate from Shandong Normal University, IEEE members, network engineer. Her research direction is computer network technology and cloud computing.

In recent five years, as the first author has published 10 papers, including EI core retrieval 1 article, Chinese core 1 , Core journal of computer society 2 , chaired provincial science and technology plan projects litem, and 3 field research subject, one software copyright, keynote speech at the international conference.

Ms. Ge, won the first prize of national essay competition in the fifth China education technology development, The third prize of China education digitisation excellent paper, The second prize of Chinese education teaching and teaching thesis, Shandong cloud and big data technology competition excellent advisor, Shandong university student information security skills competition excellent advisor, outstanding teachers at the university level, excellent thesis advisor. 